\title{
Differentiating Mouse Embryonic Stem Cells into Embryoid Bodies in AggreWell Plates
}

\author{
Mark Kibschull
}

Embryonic stem (ES) cells can develop into many types of differentiated tissues if they are placed into a differentiating environment. This can occur in vivo when the ES cells are injected into or aggregated with an embryo, or in vitro if their culture conditions are modified to induce differentiation. Many times ES cell differentiation proceeds through an intermediate stage called the embryoid body (EB). EBs are round structures composed of ES cells that have undergone some of the initial stages of differentiation. EBs can then be manipulated further to generate more specific cell types. The method described here makes use of commercially available AggreWell 400 plates with prefabricated indentations that cradle each EB. Although these plates are relatively expensive, they may be suitable for some high-throughput experiments. This protocol describes the preparation of embryoid bodies of defined size and shape in a large-scale format (approximately 1200 embryoid bodies per preparation).

It is essential that you consult the appropriate Material Safety Data Sheets and your institution's Environmental Health and Safety Office for proper handling of equipment and hazardous material used in this protocol.

RECIPES: Please see the end of this protocol for recipes indicated by $<R>$. Additional recipes can be found online at http://cshprotocols.cshlp.org/site/recipes.

\section{Reagents}

Complete ES cell medium (ES-DMEM) $<\mathrm{R}>$

EB medium: ES-DMEM with all supplements but without leukemia inhibitory factor (LIF)

(ES-DMEM without LIF)

ES cells grown on mouse embryonic fibroblast (MEF) feeder layers

Gelatin (Swine Skin type II, Sigma-Aldrich G2500) (0.1\%, w/v, in water, autoclaved)

Phosphate-buffered saline (PBS) $<\mathrm{R}>$

Prepare PBS without added $\mathrm{Ca}^{2+}$ and $\mathrm{Mg}^{2+}$.

Pluronic F127 (5\%, w/v, in sterile $\mathrm{H}_{2} \mathrm{O}$ ) (Sigma-Aldrich P2443)

Trypsin-EDTA solution $<\mathrm{R}>$

From the Manipulating the Mouse Embryo collection, edited by Richard Behringer, Marina Gertsenstein, Kristina Vintersten Nagy, and Andras Nagy.

(c) 2017 Cold Spring Harbor Laboratory Press

Cite this protocol as Cold Spring Harb Protoc; doi:10.1101/pdb.prot094169 
AggreWell 400 Plates (Stem Cell Technologies 27845; http://www.stemcell.com)

Biosafety cabinet

Cell strainers $(40 \mu \mathrm{m})$, sterile, disposable (BD 352340; http://www.bdbiosciences.com)

Centrifuges including swing-out bucket with plate holder (e.g., http://www.eppendorf.com)

Centrifuge tubes $(14 \mathrm{~mL})$, conical

Hemocytometer

Incubator, $37^{\circ} \mathrm{C}, 5 \% \mathrm{CO}_{2}, 95 \%$ air

Microscope, inverted

Pipettes

Pipettor

Tips $(1 \mathrm{~mL})$

Tissue culture dishes to grow ES cells

Tubes $(14 \mathrm{~mL})$, conical

Ultra-low-adherence plates (e.g., six-well Corning 3471; http://www.corning.com)

1. Coat the microwells of the AggreWell 400 plate with Pluronic F127 solution by adding $1 \mathrm{~mL}$ to each of those wells that contain microwells (the middle eight of the 24 wells in the plate contain microwells: B2 to C5).

Coating the microwells with Pluronic F-127 is not essential but helps to prevent EBs from sticking to the plate.

2. Centrifuge the plate at $3000 \mathrm{~g}$ for $5 \mathrm{~min}$ to remove bubbles, and incubate for $30 \mathrm{~min}$ at room temperature.

3. Aspirate the Pluronic F127 solution and wash with $1 \mathrm{~mL}$ of DMEM per well. Remove the DMEM. Add $1 \mathrm{~mL}$ of EB medium to each well and centrifuge the plate again at $3000 \mathrm{~g}$ for $5 \mathrm{~min}$. Store the plate in the incubator until use.

4. If ES cells were cultured on MEFs, follow Steps 1-4 in Protocol: Differentiating Mouse Embryonic Stem Cells into Embryoid Bodies by Hanging-Drop Cultures (Behringer et al. 2016). Otherwise, trypsinize the cells using trypsin/EDTA, centrifuge at $200 \mathrm{~g}$ for $5 \mathrm{~min}$, and aspirate the supernatant.

5. Resuspend the cell pellet in EB medium. Count the cells and dilute to a final $2.4 \times 10^{6}$ cells $/ \mathrm{mL}$ using EB media to get EBs initiated by 2000 cells. The cell density can be changed if a different initiating cell number is required.

6. Without removing the media from the previously prepared AggreWell 400 plate, add $1 \mathrm{~mL}$ of the cell suspension to each well containing microwells. The total volume in each well will now be $2 \mathrm{~mL}$. Immediately centrifuge the plate at $100 \mathrm{~g}$ for $5 \mathrm{~min}$ to distribute the cells evenly between the microwells.

After centrifuging ES cells into the microwells, check for clumps or floating aggregates. These should be removed using a P200 tip to avoid clumping of embryoid bodies.

Examine the wells under a microscope to ensure that the microwells are filled with similar amounts of ES cells.

7. Place the plate into the incubator and incubate for $2-6 \mathrm{~d}$.

Embryoid bodies can be collected from the AggreWell 400 plates as early as $24 \mathrm{~h}$ after aggregation, but they can be cultured for several days in the plates without affecting growth. Remove the embryoid bodies when they fill the size of the microwell or start clumping. 
8. Change the medium after $48 \mathrm{~h}$ by carefully aspirating $1 \mathrm{~mL}$ of the medium with a $1-\mathrm{mL}$ pipette tip, and gently add $1 \mathrm{~mL}$ of fresh medium to the wall of the well, avoiding turbulences.

When changing the medium in the AggreWell 400 plates, always leave the embryoid bodies covered with liquid to avoid formation of turbulence when adding the fresh medium. Fresh medium should be added as slowly as possible by pipetting the liquid to the inner wall of the well using a 1-mL pipette tip.

9. When the EBs reach the required size, rinse them from the microwells by gently pipetting up and down using a $1-\mathrm{mL}$ pipette tip.

10. To remove single cells and dead cell clumps, the EBs can at this point be gently pipetted into a $40-\mu \mathrm{m}$ cell strainer. Discard the flowthrough and wash back the EBs by inverting the cell strainer and rinsing with EB media.

11. Resuspend the EBs in EB medium, and distribute them between the wells of a six-well ultra-lowadherence plate. Culture the EBs until they reach the required size optimal for subsequent differentiation protocols.

Embryoid bodies should be plated at low densities in low-adherence plates for further growth to avoid clumping. When clumping is observed, further dilute the density.

\section{RELATED INFORMATION}

This method was adapted from Ungrin et al. (2008).

\section{RECIPES}

Complete ES Cell Medium (ES-DMEM)

Component Final concentration

DMEM

Fetal bovine serum (FBS) or knockout serum $\quad 10 \%-20 \%$ replacement (KSR)

L-Glutamine or L-alanyl L-glutamine ${ }^{\mathrm{a}}$

$\beta$-Mercaptoethanol (b-ME) $)^{\mathrm{b}}$ or monothioglycerol ${ }^{\mathrm{c}} \quad 0.055-0.1 \mathrm{~mm}$

Nonessential amino acids

Sodium pyruvate (optional)

$0.1 \mathrm{~mm}$

Nucleosides ${ }^{\mathrm{d}}$ (optional)

Penicillin-streptomycin (optional) $\quad 50-100$ units $(\mu \mathrm{g}) / \mathrm{mL}$

LIF

500-2000 units/mL

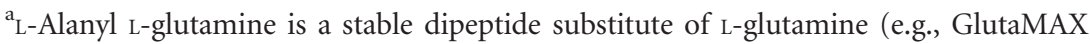
from Invitrogen Life Technologies).

${ }^{\mathrm{b}}$ Miscalculations that increase b-ME concentration are guaranteed to cause ES cell culture failure. $55 \mathrm{~mm}$ solution of b-ME is commercially available (e.g., Invitrogen Life Technologies 21985-023); alternatively, $10 \mathrm{~mm}$ stock can be made from $14.3 \mathrm{M}$ solution (e.g., Sigma-Aldrich M6250) by adding $7 \mu \mathrm{L}$ of b-ME to $10 \mathrm{~mL}$ of PBS.

${ }^{\mathrm{c}}$ Monothioglycerol is less volatile than b-ME and can be used as a substitute typically at a final concentration of $0.15 \mathrm{~mm}$.

${ }^{\mathrm{d}}$ Addition of the nucleosides was described in the original formulations for ES cell culture (Robertson 1987). It is used for culture of some ES cell lines. 100× stock is commercially available (e.g., Millipore ES-008-D). 
Producing Embryoid Bodies in AggreWell Plates

Phosphate-Buffered Saline (PBS)

\begin{tabular}{|c|c|c|c|c|}
\hline Reagent & $\begin{array}{l}\text { Amount to add } \\
\text { (for } 1 \times \text { solution) }\end{array}$ & $\begin{array}{c}\text { Final } \\
\text { concentration } \\
(1 \times)\end{array}$ & $\begin{array}{l}\text { Amount to add } \\
(\text { for } 10 \times \text { stock })\end{array}$ & $\begin{array}{c}\text { Final } \\
\text { concentration } \\
(10 \times)\end{array}$ \\
\hline $\mathrm{NaCl}$ & $8 \mathrm{~g}$ & $137 \mathrm{~mm}$ & $80 \mathrm{~g}$ & $1.37 \mathrm{M}$ \\
\hline $\mathrm{KCl}$ & $0.2 \mathrm{~g}$ & $2.7 \mathrm{mM}$ & $2 \mathrm{~g}$ & $27 \mathrm{~mm}$ \\
\hline $\mathrm{Na}_{2} \mathrm{HPO}_{4}$ & $1.44 \mathrm{~g}$ & $10 \mathrm{~mm}$ & $14.4 \mathrm{~g}$ & $100 \mathrm{~mm}$ \\
\hline $\mathrm{KH}_{2} \mathrm{PO}_{4}$ & $0.24 \mathrm{~g}$ & $1.8 \mathrm{~mm}$ & $2.4 \mathrm{~g}$ & $18 \mathrm{~mm}$ \\
\hline \multicolumn{5}{|c|}{ If necessary, PBS may be supplemented with the following: } \\
\hline $\mathrm{CaCl}_{2} \cdot 2 \mathrm{H}_{2} \mathrm{O}$ & $0.133 \mathrm{~g}$ & $1 \mathrm{~mm}$ & $1.33 \mathrm{~g}$ & $10 \mathrm{~mm}$ \\
\hline $\mathrm{MgCl}_{2} \cdot 6 \mathrm{H}_{2} \mathrm{O}$ & $0.10 \mathrm{~g}$ & $0.5 \mathrm{~mm}$ & $1.0 \mathrm{~g}$ & $5 \mathrm{~mm}$ \\
\hline
\end{tabular}

PBS can be made as a $1 \times$ solution or as a $10 \times$ stock. To prepare $1 \mathrm{~L}$ of either $1 \times$ or $10 \times$ PBS, dissolve the reagents listed above in $800 \mathrm{~mL}$ of $\mathrm{H}_{2} \mathrm{O}$. Adjust the $\mathrm{pH}$ to 7.4 (or 7.2, if required) with $\mathrm{HCl}$, and then add $\mathrm{H}_{2} \mathrm{O}$ to $1 \mathrm{~L}$. Dispense the solution into aliquots and sterilize them by autoclaving for $20 \mathrm{~min}$ at $15 \mathrm{psi}\left(1.05 \mathrm{~kg} / \mathrm{cm}^{2}\right)$ on liquid cycle or by filter sterilization. Store PBS at room temperature.

\section{Trypsin-EDTA Solution}

Trypsin-EDTA solution is used to detach cells from tissue culture dishes and to dissociate cells from one another. Dilute the $10 \times$ stock of trypsin-EDTA from the supplier (e.g., Invitrogen Life Technologies 15400-054) into Ca/Mg-free $1 \times$ Dulbecco's PBS. The final concentrations are $0.05 \%$ trypsin, $0.02 \%(0.53 \mathrm{~mm})$ EDTA. This diluted solution can be aliquoted (e.g., 5-10 mL) and stored frozen. Ready-to-use $0.05 \%$ trypsin, $0.53 \mathrm{~mm}$ EDTA is commercially available (e.g., Invitrogen Life Technologies 25300-054). It is also possible to use $0.25 \%$ trypsin, $0.04 \%$ EDTA (e.g., Invitrogen Life Technologies 25200 056) for routine culture of ES cells.

\section{REFERENCES}

Behringer R, Gertsenstein M, Nagy KV, Nagy A. 2016. Differentiating mouse embryonic stem cells into embryoid bodies by hanging-drop cultures. Cold Spring Harb Protoc doi: 10.1101/pdb.prot092429.

Robertson EJ. 1987. Embryo-derived cell lines. In Teratocarcinoma and embryonic stem cells: A practical approach (ed. Robertson EJ), pp. 71-112. IRL Press, Oxford.
Ungrin MD, Joshi C, Nica A, Bauwens C, Zandstra PW. 2008. Reproducible, ultra high-throughput formation of multicellular organization from single cell suspension-derived human embryonic stem cell aggregates. PLoS One 3: e1565. 


\section{Differentiating Mouse Embryonic Stem Cells into Embryoid Bodies in AggreWell Plates}

Mark Kibschull

Cold Spring Harb Protoc; doi: 10.1101/pdb.prot094169

\begin{tabular}{|c|c|}
\hline $\begin{array}{r}\text { Email Alerting } \\
\text { Service }\end{array}$ & Receive free email alerts when new articles cite this article - click here. \\
\hline $\begin{array}{l}\text { Subject } \\
\text { Categories }\end{array}$ & $\begin{array}{l}\text { Browse articles on similar topics from Cold Spring Harbor Protocols. } \\
\text { Cell Culture ( } 301 \text { articles) } \\
\text { Developmental Biology (728 articles) } \\
\text { Embryonic Stem Cells (55 articles) } \\
\text { Mouse ( } 437 \text { articles) } \\
\text { Stem Cells (46 articles) } \\
\text { Stem Cells, general (70 articles) }\end{array}$ \\
\hline
\end{tabular}

